\title{
Swimming Behavior in a Caspian Whipsnake, Dolichophis caspius (Gmelin 1789)
}

\author{
Oleksandra Oskyrko ${ }^{1}$ and Daniel Jablonski ${ }^{2}$ \\ ${ }^{1}$ Educational and Scientific Center "Institute of Biology and Medicine," Taras Shevchenko National University of Kyiv, prosp. Akademika Hlushkova 2, \\ Kyiv, Ukraine (sashaoskirko@gmail.com) \\ ${ }^{2}$ Department of Zoology, Comenius University in Bratislava, Mlynská dolina, Ilkovičova 6, 84215 Bratislava, Slovakia (daniel.jablonski@balcanica.cz)
}

$\mathrm{T}$ he Caspian Whipsnake (Dolichophis caspius) is primarily an inhabitant of the steppes that stretch across the western Palearctic from the Carpathian Basin to the western shores of the Caspian Sea, including the northern Caucasian region (Sindaco et al. 2013). The northernmost localities in its European range are in northwestern Hungary and Ukraine (Schcherbak and Böhme 1993). This species is widely distributed in the steppe zone of Ukraine and the Crimea (Kotenko and Kukushkin 2005) and is listed in the Red Book of Ukraine (Akimov 2009). In these areas, the average population density rarely exceeds one individual per $\mathrm{km}^{2}$, although some local areas support higher densities (Kotenko 1993; Kotenko and Kukushkin 2005).

On 29 April 2019 in the Southern Bug River (= Pivdennyi Buh) at Grushivka Village, Pervomaisky District, Mykolaiv Region, Ukraine $\left(48.02^{\circ} \mathrm{N}, 30.94^{\circ} \mathrm{E}\right)$, we observed an adult Caspian Whipsnake, approximately $1 \mathrm{~m}$ in total length, swimming from open water $3-4 \mathrm{~m}$ from the bank toward the shore (Fig. 1). The rate of flow at the site was slow. The snake swam quickly with its head elevated, a style of swimming quite similar to that of a Dice Snake (Natrix tessellata), a common semiaquatic species in the region (Kotenko et al. 2011). After reaching the shore, the snake moved into the reeds where it disappeared from sight.

Swimming by this typically terrestrial snake is an unusual behavior that, to the best of our knowledge, has never been reported until now. Swimming, however, is common in sympatric Dice Snakes and retreating into water is a frequently employed escape strategy. On the other hand, the most common defensive behaviors of $D$. caspius include active measures, such as striking at the perceived threat and biting (Kotenko 1993; Kotenko and Kukushkin 2005).

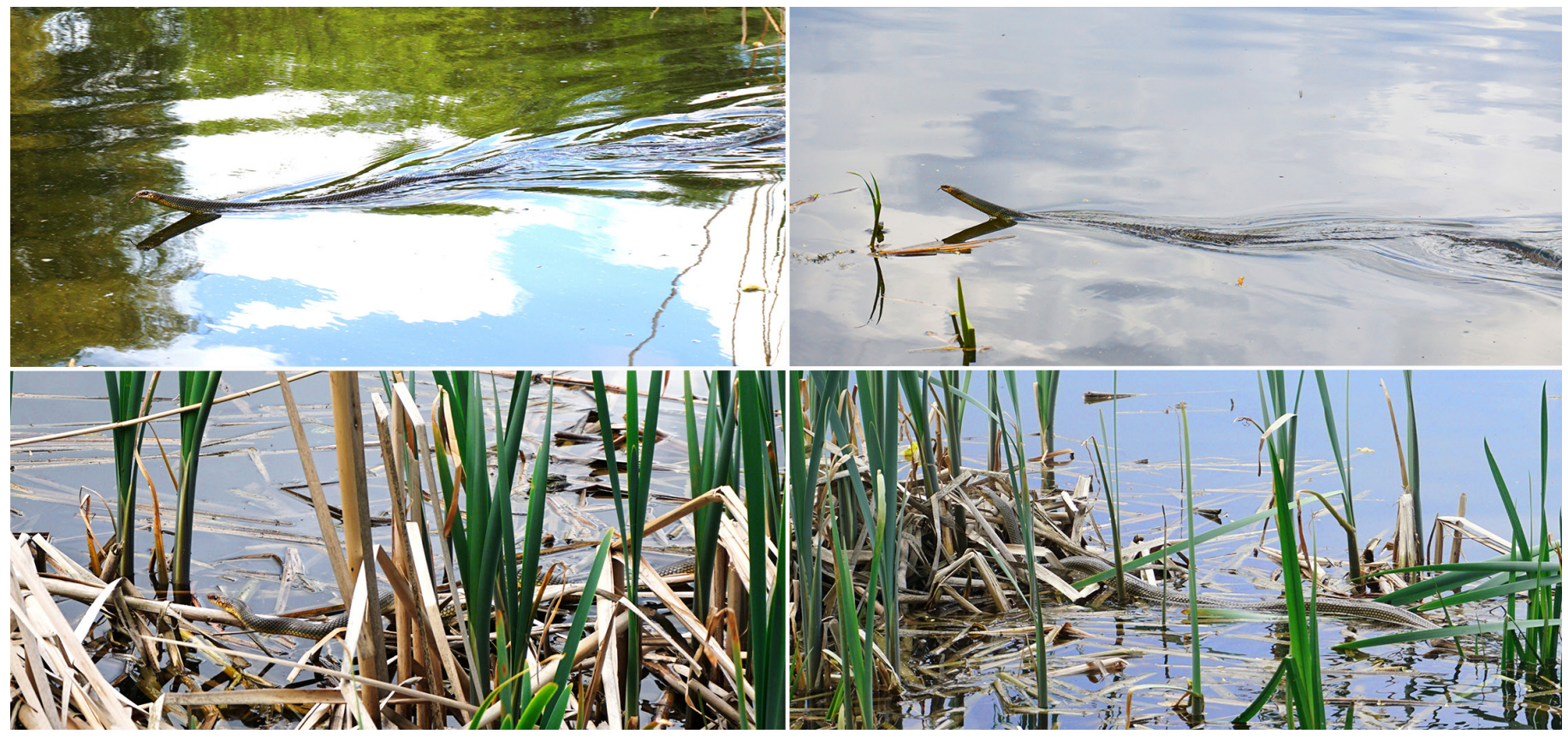

Fig. 1. A Caspian Whipsnake (Dolichophis caspius) swimming in the Southern Bug River at Grushivka Village, Pervomaisky District, Mykolaiv Region, Ukraine. Photographs by Dariia Shyriaieva. 
Swimming has been observed in other largely terrestrial species of reptiles. For example, Adders (Vipera berus) have been observed swimming and even diving in the Baltic Sea (Rehák 1992; Märtson et al. 2001). The Slowworm (Anguis fragilis), a legless lizard, is known to swim (Dathe 1971; Gollmann and Gollmann 2008), and various other largely terrestrial lizards use swimming to catch prey, escape predators, or control body temperatures (e.g., Lin et al. 2008; Blanke 2004; Gollmann and Gollmann 2008). In fact, several aspects of reptilian physiology, including lower metabolic rates and larger lung volumes compared to mammals, render even terrestrial reptiles capable of surviving in aquatic habitats if needed (Heatwole 1977; Hare and Miller 2009). An apparent willingness to swim also supports the conclusion that xerotolerant Caspian Whipsnakes are exceedingly mobile and exhibit traits that enhance their ability to migrate (Zinner 1972; Schcherbak and Böhme 1993).

\section{Acknowledgments}

This contribution was supported by the Rufford Small Grant "Assessment of conservation status of habitats important for reptiles within the Southern Bug eco-corridor in the Steppe zone of Ukraine" (ID 28002-1) and by the Slovak Research and Development Agency under contract no. APVV-150147. We thank the administration of Buzk's Gard National Nature Park for their support of the research and Dariia Shyriaieva for photographic documentation.

\section{Literature Cited}

Akimov, I.A. (ed.). 2009. Coluber caspius, pp. 210-211. In: V. Herasymchuk (ed.), Red Data Book of Ukraine. 3rd ed. Global Consulting, Kyiv, Ukraine (in
Ukrainian).

Blanke, I. 2004. Die Zauneidechse: zwischen Licht und Schatten. Laurenti Verlag, Bielefeld, Germany.

Dathe, H. 1971. Zum Schwimmen der Blindschleiche, Anguis fragilis. AquarienTerrarien 18: 65.

Gollmann, G. and B. Gollmann. 2008. Diving in the lizards Anguis fragilis and Lacerta agilis. North-Western Journal of Zoology 4: 324-326.

Hare, K.M. and K.A. Miller. 2009. What dives beneath: Diving as a measure of performance in lizards. Herpetologica 65: 227-236.

Heatwole, H. 1977. Sea snakes, a contrast to other vertebrate divers. Journal of the South Pacific Underwater Medicine Society 7: 35-38.

Kotenko, T. 1993. Rare colubrid snakes of the steppe Ukraine, p. 85. In: Program \& Abstracts. 7th Ordinary General Meeting of Societas Europaea Herpetologica. 15-19 September 1993. Barcelona, Spain.

Kotenko, T.I. and O.V. Kukushkin. 2005. Large whip snake - Coluber caspius Gmelin, 1789. Collection of Scientific Papers 1: 259-262 (in Ukrainian).

Kotenko, T.I., S.V. Shaitan, V.G. Starkov, and O.I. Zinenko. 2011. The northern range limit of the dice snake (Natrix tessellata) in Ukraine and the Don River Basin in Russia. Mertensiella 18: 311-325.

Lin, C.X., L. Zhang, and X. Ji. 2008. Influence of pregnancy on locomotor and feeding performances of the skink, Mabuya multifasciata: why do females shift thermal preferences when pregnant? Zoology 111: 188-195.

Märtson, M., M. Taittonen, M. Alanen, and M., Reunanen. 2001. Vipera berus adder bite in the water, complicated by rapid shock. A case history. European Journal of Pediatric Surgery 11:358-360.

Rehák, I. 1992. Vipera berus (Linnaeus, 1758), pp. 154-172. In: V. Baruš and O. Oliva (eds.), Fauna C SFR. Sv. 26. Plazi. Reptilia. Academia, Praha, Czechoslowakia (in Czech).

Schcherbak, N.N. and W. Böhme. 1993. Coluber caspius Gmelin, 1789 - Kaspische Pfeilnatter oder Springnatter, pp. 83-96. In: W. Böhme (ed.), Handbuch der Reptilien und Amphibien Europas, Band 3/I, Schlangen (Serpentes) I. AULAVerlag, Wiesbaden, Germany.

Sindaco, R., A. Venchi, and C. Grieco. 2013. The Reptiles of the Western Palearctic. 2. Annotated Checklist and Distributional Atlas of the Snakes of Europe, North Africa, Middle East and Central Asia, with an Update to the Vol. 1. Societas Herpetologica Italica, Edizioni Belvedere, Latina, Italy.

Zinner, H. 1972. Systematics and evolution of the species group Coluber jugularis Linnaeus, 1758 - Coluber caspius Gmelin, 1789 (Reptilia, Serpentes). Unpublished Ph.D. thesis, Hebrew University, Jerusalem. 